\title{
CONSTRUCTING BLACK MASCULINITY IN OLIVER PARKER'S OTHELLO (1995)
}

\section{Tarik Bouguerba*}

\begin{abstract}
This paper examines Oliver Parker's Othello (1995), an excellent American filmic production of Shakespeare's play**. The article also offers a reading to Oliver Parker's film production of Othello (1995) where the story offers yet an opportunity to explore anti-Black sentiment in the American society with focus on black masculinity. Othello is therefore portrayed as "indolent, playful, sensuous, imitative, subservient, good natured, versatile, unsteady in their purpose... they may but be compared to children, grown up in the stature of adults while retaining a childlike mind". (cf. Collins 1996: 89) $)^{* * *}$
\end{abstract}

This article is particularly interested in how Parker's Othello fetishizes the black male body through exploiting the racialist dogmas about black Americans. Heavily punctuated with flashbacks, this production constructs a two-fold narrative; one approaching the plot from a traditional perspective whereas the other dealing with a rightly African American subjectivity.

In conclusion, although Oliver Parker's rendition of Shakespeare's Othello preserves much of Shakespeare's poetry, it is however a new mediatising form produced at an age "the white elite uses filmic representations of African Americans" as means to control and even contain race relations in the USA. (Hogdon qtd. in Aldama 2006: 198)

Key words: Black masculinity, black bodies, the politics of screening, racism, Shakespeare.

In 2008, Obama was elected the $44^{\text {th }}$ president of the United States of America, sworn in on January 2009.*** That was by all accounts a historic moment, making him the first black man to be living in the white house and running America's

\footnotetext{
* PhD at Ibn Tofail University, Kenitra, Morocco, e-mail: tarik_mahdi@yahoo.fr

** Shakespeare's Othello is, by all means, a universal text in that it could still be adapted to all contexts. This paper examines how the source text travels through regions where racial issues still matter.

*** With the exception of the good natured asset of the Moor that only flows out from the camera lenses, other derogative attributes apparently manifest in both American film productions of Othello: Tim Blake's and Oliver Parker's. Perhaps, Liz White's (1980) Othello stands out as the only attempt to liberate Shakespeare's text from the racial conflict based originally on color, casting Iago himself as black.

**** In this context, Obama is an Othello of modern times who would rescue the USA politically and economically as did Othello back in the Renaissance.
} 
state and foreign affairs from the oval office. Once again in 2012, he was reelected to this very office to lead America for yet another term and take the country to war if he sees fit. About a decade earlier and exactly in February1998, Kofi Anan, in his capacity as the Secretary General of the United Nations, was dispatched to Iraq in the hope of warding off the threat then posed by Saddam Houssein. In a mission of this nature, Anan's colour was not relevant to the sensitivity of the historical context because it had never been the norm.*

In the context of the world order, such political incidents, which recall the story of Othello's dispatch to Cyprus, could be considered as part of the "ride to the rescue of the civilized world".** In Othello, white Venice's communal sense of the traits that distinguish a Venetian from an outsider is similar to what I advanced earlier with regard to our modern times. Venice sends Othello, a Moor, to Cyprus to fight the indomitable turbaned Turks.

Several film productions have cast Othello in quite favourable light with regard to cultural relations he entertains to the city-state and at times his predisposition to assimilate to the White Venetian culture to the extent that he betrays resistance, even resentment of this new identity..** Oliver Parker's Othello, which came seventy three years after the first adventure by Dmitri Buchowetzki's 1922, strikes higher artistic scores in a subtle balance of Shakespeare's poetic

* The phrase 'rescue ride of the civilized world' was borrowed by Judith Buchanan (2002: 179) from Wall Street characterization of the dispatch to Iraq.

** See Graham Holderness's Shakespeare and Venice for details on Venice as a myth. In 1599, the English poet I. Ashley concluded his sonnet with the following line, emphasizing the mythological conception of Venice as a site for tolerance and cultural difference 'enamoured like Narcissism thou shalt dye'. (Platt 2009: 69). In my view Modern England, democratic America and (Post)-Apartheid South Africa replicate and duplicate the same myth of Venice as a place whose image had been constructed partly to gratify its thrust and lustful desire to think well but of its own image. This ideal image of Venice is therefore reproduced through the camera lenses of Orson Welles and Oliver Parker. Parker's Venice, in particular, resembles Shakespeare's in its eternal love with its own image. Through Oliver Parker, Venice believes the myths it has invented about itself. The new world Parker imagines for his own replica of Venice is one of the best reflections ever made on screen. His is a city whose very architecture dictates that it gaze, in voyeuristic terms, constantly and persistently upon its own questionably beautiful image. (cf. Buchanan 2002: 183). Other historical incidents would be that blacks and other North African agents served in the French Army in the World War in defense of White France.

*** Other Othelloes who rejected this new identity are Laurence Olivier who betrayed the great expectations of the Venetians as he was the black infidel interrogating the image of the British Empire and invoking the threat both at the economic and political levels brought by black immigrants. Welles's Othello has also resented the new identity although Parker's Othello, in my view, made of its Othello assimilate to the social etiquette of Venice invoking once more the position of black African Americans in the USA. 
dialogue with super-imaginative cinematography. If in other film productions of Othello the Moor is represented as a man trying to erase, if not efface or at least minimize, the existing social and physical distinction, Parker's (1995) is a production that aligns itself with the position of Othello, a man willing to go public with his resistance to his context. (Buchanan 2002: 182) Laurence Fishburne, the first black actor to have played the Moor of Venice in a commercial cinema production, is an incarnation of a Moor whose native identity pushed him far afield from being a Venetian. The screen play of the film is clearly fuelled by desire and passion. Oliver Parker could have imagined no better interpretation than this represented by flows of passion and desire. He thus reconceived of Shakespeare's grand tragedy as follows

I saw the play as an erotic thriller, and that is what I wanted to translate onto the big screen. Passion is the driving force of the story. Each character is motored by desire. There is an extraordinary fusion of people boiling with different passions.**

Our first encounter with Fishburne is therefore a delayed close-up of his prominently scarred hand taking Desdemona's flawless chaste hand in the course of their clandestine marriage ceremony. It is by all means a striking introductory image of White-Black encounter. ${ }^{* * *}$ Judith Buchanan has described how Fishburne's posture as "an arresting physicality", as it contributes to his unapologetic otherness, is undeniably part and parcel of his attraction.(Buchanan 2002: 182) His skin colour, stature, behaviour, earrings, strange gestures, and half-mocking ambiance make him less the best exemplaire- exemplum of Venice, yet an exotic outcast resented and rejected within its very social fabric.

Every aspect of Parker's film production interrogates Othello's position in Venice and interrupts his natural willingness to lead a military campaign against the Turbaned Turks. The narrative pace of the opening sequence, with its shifts from location to location, and movements of characters in the darkness of night time allows for a sense of exigency against which Fishburne can move and speak, yet with a constant, vigilant upper eye riveted on him. Other scenes emphasize this rejection. Having a white female and a black male carried together, the black male-Othello- is caught on camera covering his face with a white mask marked with a stroke of blackness, the mask of his own destruction, his own tragedy.

\footnotetext{
* The film merges Laurence Fishburne's excellent portrayal of difference with Kenneth Branagh's amazing endorsement of natural villainy.

** See Othello Production Notes by Castle Rock International, (as found in the BFI micro jacket), dir. Oliver Parker, prod. Luc Roeg and David Barron. p.9.

*** It refers to the encounter through which Oliver Parker invokes other confusing encounters between white masters and their black subjects. It is always punctuated by moments of fear and others of fascination.
} 
While this sense foregrounds Othello's difference from the Venetians, it marks a significant moment in the tragedy of the Moor, a tragedy that is punctuated by constant feeling of rejecting or at least questioning his position in Venice."

Other instances of rejection and exclusion from Venice would be evident in the foregrounding of the cross, the symbol of white Christendom. In Burge-Dexter's British filmed theatre production, the Christian cross, being paradigmatic of the Moor's non-alignment to White Christian Venice, is worn with pride. In Parker's film, the blue gun around Othello's neck is not adorned so prominently as Olivier's cross in Dexter's film. Such a choice on Parker's part marks Fishburne's Othello out as a man from a place ruled -ruined in their view- by different cultural conventions. Other insignias Fishburne wears around his neck are mere ornament or decoration. At the closing scene of Parker's film, Othello pulls it tight around his neck as he stabs himself. In Parker's, Othello dies from constant refusal and steady denial to break free from his traditional cultural attachments and fully embrace mythological Venice's value system.(Buchanan 2002: 183)

Given Parker's long established views on race and interracial marriage and as well as his conceptions of Fishburne's Othello and Branagh's Iago**, I feel that there is clear attempt at his fetishising the black male body. Parker assigns Othello to the visual and Iago to the verbal. Indeed, Parker's Othello is demarcated chiefly by grand images. The steady visual references to water inscribe Othello in flamboyant otherness. Although Othello is clearly distinguished through his Moorish appearance, he is ultimately pinned down to mere racial stereotype. Such visual choices can be construed as a representation of Othello's disturbed mental state as well as of his own alien persona. Fishburne's Othello is thus the disgusting exotic, violent, uncivilized other. ${ }^{* * *}$

I would thus examine the film through a socio-political paradigm which conceives of the black male body as a palimpsest. If black women have succeeded in culturally defining themselves in their own terms, the black male has always failed

\footnotetext{
* Endorsing a postcolonial stand, Fishburne's Othello is not only rejected across Venice as he - a black African American- is excluded from their entire social life in the USA.

** When you watch this film production, it seems that the Oliver Parker has managed to produce a version of Shakespeare's Othello who is stripped of his identity. Parker failed to play down this racist town in the source text.

*** The other argument is that Oliver Parker invokes once again black tragedies in the history of the United States. The protagonist, Laurence Fishburne, is therefore reminiscent of another victim of this American institutional systematic racism in white schools. Overempowering Branagh's Iago is another instance of this institutionalizing-at times populist- mode of racist or racialist attitudes Shakespeare's text erstwhile provokes. I think of Parker's film as a pertinent statement on the difficulties Black African Americans are still facing in the United States of America once caught crossing colour boundaries.
} 
to identify itself.(Wallace 2002: 1)* My approach to Parker's film production and the ideological tactics inherent in its conception of Fishburne's body emanates from a western version of race. The high profile of race in the west- America in particular- has created out of the black masculine body a walking palimpsest of fears and fascination possessing their cultural imagination. ${ }^{* *}$ Fishburne's endless physical strength therefore emphasizes the stereotypical image of the black male body as the impetus for desire and passion. ${ }^{* * *}$

If Shakespeare's Moor has entertained a long history as a mercenary, 'an extravagant and wheeling stranger,' Fishburne's half-sneering, half-mocking, powerfully physical, if not sexual, presence makes him convincing in such a role. It is Fishburne's black body that makes of him the best to play the role of the Moor and at the same time his version of blackness has also cast him outside Venice. Although standing distinct from other white native inhabitants, Fishburne's Othello interrupts and interrogates the mythological image of Venice.( Buchanan 2002: 183) Contributing to the cinematic merit of this adaptation of Othello, one of the audacious changes Parker's approach brought to Shakespeare's text is that his Othello is a Moor who is much fascinated by an image of himself which he erstwhile fashions carefully for Desdemona as well as for the public consumption. Fishburne's fascinating body successfully encourages others to gaze upon it. (Ibid) Judith Buchanan goes even further to construe that as Parker's camera aligns itself sporadically with Desdemona's lustful gaze throughout the entire film, Fishbrune's body is eroticized by its visual strategy.(Ibid.) ${ }^{* * * *}$

\footnotetext{
* See introduction to the book.

** Following the same line of thinking, Oliver Parker seems to have reproduced the same western clichés out of a fixed image of the black male body. This fixity characterizing the black male body has yet generated hot debates namely amongst poststructuralist scholars such as Michel Foucault, Jacques Lacan, Juliet Mitchell who have imagined the black men as paradigmatically at the centre of their critical insights. In my reading of Oliver Parker's cinematic work, Fishburne's physical strength seems to have emphasized the fact that in the history of the New World race has constituted a defining feature of American National Manhood. (Ibid). The film, in my view, is also paradigmatic of a new chapter in the history of America, a history that reviews the centrality of the black body in the popular imagination of Americans.
}

*** Perhaps Parker was aware of how in modern popular imagination manhood was an endless rivalry for the power and privileges of patriarchy animated by the psychic discomfiture of men's mutual fears and desires for one another namely in sexually changed contexts. (Wallace 2002: 1) His Desdemona does not only see Othello's 'Visage in his mind'. She is also fascinated by his sexual performance incarnated in his black body.

**** For example, in the night of their arrival in Cyprus, it is his undressing but not Desdemona's upon which the camera generates acts of relentless voyeurism, and it constantly lingers with some unprecedented intimate appreciation. It is Iago's desirous gaze upon Othello's 
If in all film productions of Othello, the hero fully endorses Christian values, Parker's production, mainly in its perception of the Moor's identity, emphasizes Othello's disturbed vision, if not version, of his origins. Albeit aligning himself with Venice's ideal values and its cosmopolitan social system, Parker's Othello turns his back on his past. Even his perception of the concept of 'black man' seems to have been inherited from a culture openly claiming some form of antagonism to all things not white. (Buchanan 2002: 196)

In my understanding, this Oliver Parker's authentic production of the Tragedy of the Moor of Venice therefore fails to divest the original Shakespearean script of its misconceptions of 'colour' as a significant sign of otherness. Parker has his Othello speak of Desdemona not as a victim of black colour. "Her name, that was as fresh/ as Dian's visage, is not begrimed and black/ As mine own face" (III;III). This Venetian view of colour difference, as it reflects how within the USA itself colour has always been and still is a socio-cultural marker, has permeated Othello's own perception of his origin."

Only through Parker would Othello initiate to behave in total harmony with the Venetian social system. Although his Othello resists all forms of Christianization, white-Americanization, and blaxploitation $^{* *}$, I should contend that in this 'faithful adaptation' of Shakespeare's tragedy, Othello participates in writing Christian Venice's stereotypical image of the 'infidel Moor' in bold as superstitious, irrational, crude, unsophisticated and dangerous. However, the intruding flashbacks into Shakespeare's dogmatic text would only affirm that Othello is, by nature, the emblem of natural villainy and whatever the attempts to moderate and turn down the racialist tone of the play, the film production would but perpetuate and accentuate these disparaging attitudes towards blacks in one more a stereotypical model. Parker's Venice and its multi-cultural ideals had constantly been at pains to reassure that this Othello was not that irrational or dangerous despite his Oriental origins.(Buchanan 2002: 196) If Shakespeare's Othello is historically thought of as "the most emphatically Christian" of all Shakespeare's tragic heroes, Parker's is an Othello who subsequently resents and resists all forms of Christendom.(Rabkin 1967: 63)

body -into different scenes of the film- that is not free of some amazing attraction.

* Such a mental disturbance Othello suffered throughout Shakespeare's text has been better illustrated in Parker's film production (1995) through a relentless series of flashbacks where scenes of imagined adultery penetrating and infiltrating the Moor's mind. Only through these flashbacks would Othello submit to and admit these stereotypical images of Moors -Black Americans- as superstitious and suspicious.

** Blaxploitation blends Black and exploitation: The term explains how blacks have constantly been exploited by whites throughout human history. 
Parker's Othello seems to have been narrating not in a Moorish context but rather recounting an African American subjectivity. In reconstructing legal subjectivity, for example, the presence of a body marked as black or any other historically off-margin group became a frequent strategy to represent epistemological gaps existing between racial groups.(Schur 2009: 32) Unlike other productions, this film version of 1995 reassures itself that Fishburne's Othello validates the premise that in American visual culture there has always been an extensive reliance on black bodies. (Ibid.: 45) This far too complex a relationship between the black body and the in-surveillance white voyeuristic gaze shows in details through the film that the body is persistently used to represent the dire need of both the black community, and it extends further to saturate the lustful needs of communities in white. (Ibid.: 44$)^{*}$

What chaos Fishburne's body invents in movie-theatre goers' mind states bluntly that black bodies are often used as "tools of unreason". (Ibid.: 44) Parker's film production of Othello perpetuates such stereotypical images entrenched in the psyche of American white audience. After Fishburne's formidable performance of the Moor, blacks seem to be incessantly cast in roles that deform, distort, interrogate black realities and even confirm racial stereotypes. (Ibid.: 67) In no way possible did the film succeed in changing, at least partially, the way how whites receive colour difference, but it has even perpetuated a racialist tradition in which white standards of black masculinity have perhaps dehumanized black men. (Ibid.: 138) How a white would react had 'a black ram' stolen a 'white awe' is confirmed more than once in the excessive surveillance communicated through Parker's camera lenses in its orientation to watching Fishburne's body from Iago and Desdemona's points of view. Parker also works out these traits of white surveillance so that the black male body is marked as a 'vulnerable site' through the omnipresence of -the white upper-hand- the white gaze. (Ibid.) I would also contend once again this black male body has always been "a proxy or a metaphor" for racial subjectivity. (Ibid.: 43)**

It is also true that Oliver Parker would even invent 'a complex space' wherein Othello, 'a black man', could explore the limitations and the constraints of his

\footnotetext{
* 'The black body is used to represent the needs of multiple aspects of the African American community'. (Ibid). Perhaps, the African American community is becoming proud of how an African in origin occupies such a role in a country so complex in its complexion as is America. How the white community interferes in this relationship Parker perfectly demonstrates in his adaptation of Shakespeare's Othello is evident in the way that both Desdemona and Iago lustfully, and at times discreetly, gaze at Othello's well-built over-masculine body throughout the entire production.

** Such metaphors Fishburne's physical strength generated show in the way that the black as violent, irrational, superstitious and even dangerous becomes a recurrent stock shot film makers extensively confirmed in their use of the black male body.
} 
own personal active agency under the steady voyeuristic surveillance of the white (fe)-male gaze. If such an act of starring at Fishburne's body merely legitimizes and grants the whites the upper hand over black subjects, another counteract would be generated. Throughout this faithful version of the play, Parker's Othello suffers "a black male inferiority" complex.(Schur 2009: 138) The film maker manages to produce an American Othello living in a tense relationship in which the black African American male body is a threat to the entire established binary fashioned by white prejudice. If in other adaptations of Othello the hero is divested of his masculine presence, the Parker's production contends that the black male must constantly be made to relinquish his peculiar masculinity through a series of mandatory acts including conventional submission to white supremacy, violence against white female subjects and surveillance...(Ibid.)*

Discussing this white gaze in wider terms, the other contributing items of this complex term would contribute to the traits of belonging and otherness in Parker's Othello. If Shakespeare's portrait of Othello's Moorish origins is intended to indicate a Muslim background, (see Buchanan 2002: 180) Parker's is an Othello who stands out proud of his Oriental origin and shows up resisting all forms of going Venetian. No matter how distorting if not deforming Parker's camera was in its strategy to represent Moorishness in its Negro-American context, much of Shakespeare's digression seems to have been restored so that Othello, 'albeit... a More', is noble, courageous, dignified, experienced in battle, well-born and a convert to Christianity. Through Parker's screen play, the Venetian Senate would also consider that Othello is "not altogether unworthy to be regarded" despite his colour and culture. (Ibid.: 181)

Given that this good natured Othello Shakespeare fashioned derives its traits from Greek tragedy, Oliver parker seems to have merely reproduced a model of Othello who is much representative of Aristotle's maxim

A man not preeminently virtuous and just; whose misfortune, however, is brought upon him not by vice or depravity but some error of judgment, he being one of those who enjoy great reputation and prosperity... the change in

\footnotetext{
* In my view, Parker was aware enough of the importance of this power-relation governing the tense relationship between authoritative hegemonic white gaze and the submissive violent black body. The black body is therefore significant for the superiority granted to white agents compared to the inferiority complex the black suffers in his dealing with whites.

** Such I designated as sort of digression in Shakespeare's play is a virtue being told and retold through most Western literary writing on Moors. These I would locate in Parker's film describing the Moor as good-natured are mere gaps characterizing narratives on Otherness once its normative disparaging mode of narration is turned down to speak some truth about the nature of these 'our Moors'. Parker's disputably modernized reading of Othello would but track the same disparaging rite of representation with some remarkable change in the act of writing Moorishness.
} 
hero's fortunes must be... from happiness to misery; and the case of it must lie not in any depravity, but in some great error on his part; the man himself being either such as we have described, or better, not worse, than that."

At the film's introductory scenes, Fishburne's Othello appears as a black man who defies and challenges many of Venice's great expectations about black men. Othello is therefore "noble, dignified, articulate, and restrained." (Buchanan 2002: 192) In the same vein, he is 'far more fair than black' and he does not live out the stereotype of a black who is passionate, irrational, barbaric, libidinous inarticulate and brutal.(Ibid.) If through the eyes of American audience Paul Robesson has written that Shakespeare's play is "strikingly contemporary in its overtones of a clash of cultures of the potential acceptance of and consequent effect upon one minority," (Robesson 1995: 391) Parker's artistic adaptation of the tragedy does not update its source drama to modern times, nor does it plainly draw out any contemporary parallels. On the contrary, Parker's film builds its narrative line from contemporary allusions of all kinds and at the same time establishes its confidently historical (1570) setting; the production therefore has evidently achieved some unprecedented stylistic excellence. (Buchanan 2002: 190) ${ }^{* *}$ In my judgment, the film production under study seems to understate Shakespeare's narrative and it subsequently overstates the new modern phase of Othello's life.

Unlike other Shakespeare films of the time, Parker's film production also explores fascinating locations and pinpoints the best labelling of otherness through its unstable shifting subjectivities, the traits upon which the concept of alterity is constructed. The film does also depict a cosmopolitan Venetian world, trying to represent itself as the emblem of a multicultural zone. ${ }^{* * *}$ This zone is predisposed to warmly embrace the exotic other and at times not to hesitate in deploying this alien other on useful service in the ultimate pursuit

\footnotetext{
* In all other film productions of Othello, the Moor is also much a replica of this tragic character Aristotle designated its traits in his Poetics. (see Jones 1962: 13, 19).

** I would definitely disagree with Buchanan to state that although Parker's production strides afield from all contemporary mediatizing forms - unlike other 90's Shakespeare films-, the film manages to draw parallels to current issues in modern America. In the remains of this chapter, I would examine the con-texts where Fishburne's tragedy becomes the tragedy of modern times: The Simpsons.

*** Such an image of the Venetian society as ideal as this imagined by poets is also derived from a cosmopolitanism view that "is usually seen as a liberal project towards an inclusivity of radical diversity". (Rovisco, Kim 2014: 103) This image of the city as tolerant as Venice being produced in the films draws also on "the imagination towards new forms of community and new ways of being that aid the cosmopolitanism project". (Ibid.: 115). Oliver Parker (1995) produced Venice as a myth where all live together in peace. However, this image is always contrasted with what is labelled as "failures of cosmopolitanism" where whites would resist the black threat in all forms. (Ibid.: 123)
} 
of its own interests. In this film, Othello's reaction is finally to overstate and even exaggerate Fishburne's otherness in Venetian terms by identifying himself dramatically with "the infidel Turk". (Buchanan 2002: 198)

The film even incorporates Othello into the heart of Venice's values and its social systems so that his refusal of Christian values, for example, reflects the merit of the original text to the modern age. ${ }^{* *}$ However, Othello would unexpectedly come to rescue and protect the virtues for which Venice stands. Amenable is he to being fully engrossed into Christendom that he even accepts to be commissioned to fight for its interests and ward off the foreign threat. (see Buchanan 2002: 196)

Nowhere than in Parker's production is Othello visually established as distinct from other Venetians. With a clean-shaven head, remarkable stratifications into the shaven scalp immediately above his ears, and prominent facial features, Parker's Othello is therefore becoming symptomatic of the outlandish, if not savage, black American. (Davies 2011: 15) (*** $^{* *}$

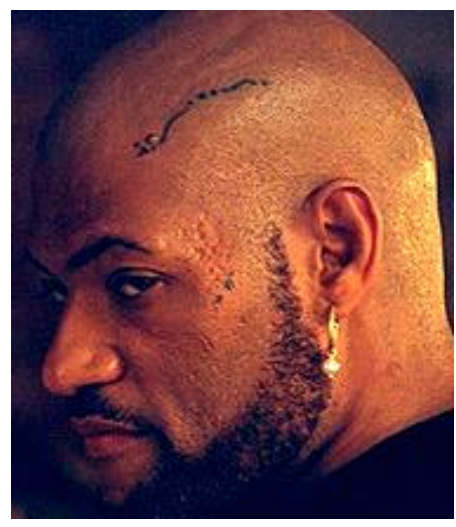

Othello

Othello, in this case, is the producer of fear and fascination, desire and horror. Fishburne has therefore gained some spectacular space in the film so that Othello is even given moments to parallel, caricature and parody 'Saint' Iago's domineering, imperious and directorial 'gaze' which determines subsequent

\footnotetext{
* This is unequivocally reminiscent of Iago's striking speech in both Shakespeare's text and parker's subtext that "[he] follow[s] him to serve [his] turn upon him".

** I think that even in the entire play, Othello resists all Christianizing forms.

*** Probably, Parker was rather thinking of producing an Othello outside his outstanding Moorish outlook and more of a Negro in its American definition. Othello is therefore to invoke traits of the black American as the dangerous drug-dealer, if not the image of the black in American prisons.
} 
camera angles.* Only through Parker's excellent camera could the spectator follow the sequencing and scenes from Othello's point of view. Through Othello's speech 'look where she comes', the camera work therefore creates the illusion that the Moor -the Black American-, like Iago, can control and manipulate the spectatorial gaze. (see Buchanan 2002: 188).** This emerging power Parker attributes to his Othello is confirmed through his relentless desire to dominate the others. This desire is not only communicated verbally as is the case in the original Shakespearean text, but it is rather articulated so tacitly through a constant emphasis on Fishburne's physicality. Parker's montage also offers an arresting, stunning, and impressive spectacle of a "militant sexuality", to use Robert F. Willson Jr's phrase. This 'militant sexuality' is spectacularly performed and celebrated by focusing on the powerful upper part of Othello's appealing black body, panning up his bare feet towards his long legs, and finally offering a medium close-up shot of his hands removing his black belt. Robert F. Willson, Jr. writes that Parker's Othello "marches towards [Desdemona] like the conquering soldier." (Willson 2002: 38)

It is through Parker's camera grammar that we are introduced to a rather wellestablished Othello even at moments of despair. The film therefore dictates our response and reaction too vehemently by convincing the spectator of aligning with Othello's split visions. Carol Rutter writes:

Parker's sensationalizing literalism requires spectators [...] to see what Othello sees, the fantasy become reality, so it makes Fishburne an Othello who has ingested, incorporated Iago's suggestions which his imagination then literally writes on to Desdemona's body in a series of images that work, perversely and reductively, to instantiate and validate the misogynistic stereotypes ('she must have change, she must') that Shakespeare's play circulates. This Othello sees Desdemona in bed with Michael Cassio and so do we. (see Rutter 2000: 255-256)

In Parker's version, Othello's conscientious ambition to an active agent is also most perceptibly validated when Desdemona dances for him and the other guests after their victorious arrival on Cyprus. Excellent has Parker been in granting Fishburne the upper hand-the upper eye- over other white subjects so that the persistently attentive surveillance of her body substantiates and confirms in

\footnotetext{
* In this production, Iago is, by all means, the hero of the piece. Othello is also represented as another hero as opposed to other film productions where Othello is the victim of Iago.

** In this case, the black masculine body becomes therefore a site for admiration and resentment at the same time. Fishburne was able through the entire film to submit to the dominant white gaze, at times, to write back to its frustrating politicized role, and subsequently to control it, resend to its sender and ultimately produce a similar vindictive gaze. By using these 'gaze traits', I am rather thinking of Malek Alloula's Le Harem Colonial on the representation of women in French colonial postcards.
} 
details Othello's voyeuristic power upon his Desdemona.* It is this Othello and not Shakespeare's that has become both a voyeur and predator. Parker's attempt to well situate his Othello is maintained even in his sexual encounter with white Desdemona. In this encounter, Parker adds a further disturbing, if not titillating, opposition that of 'desire and fear'. Such a contrast Parker inserts in Shakespeare's dramatically tense narrative contributes largely to the troubling rereading experience of the story in its Venetian-American context.

In setting out to delve into the dynamics of the dialectic relationship holding a Shakespearean play with its film adaptation, I believe that an adaptation might be faithful to the original text as it may stand out as an independent narrative, reflective of contemporaneous and contemporary issues.** Parker's film therefore became "a palimpsest on which were inscribed both its own intended Shakespearean story and a closely related through accidentally acquired, contemporary narrative.'(see Buchanan 2002: 194) This production of Othello was released at a time another indispensable narrative of the same constituents enchanted-enthralled the entire country once played out on local TV channels. The film therefore was released in the USA just instantly after the altitude of 'the media hysteria' covering the most critical trial of American history of the black American soccer player, sports commentator and actor, O.J. Simpson, accused of murdering his ex-white beloved wife, Nicole Brown Simpson and her white friend Ronald Goldman.(Ibid.: 193) The fact that Oliver Parker's film was released during this Simpsons Case era reinforced something already present in the film narrative, the theme of 'wife abuse'. The other parallel is that the actor playing Othello, Fishburne, was best known to the American public for What's Love Got to Do with It (1993), the story of Ike Turner's abuse of his wife, the Rock singer Tina Turner. This film story has unequivocally lent a meticulous intensity to Othello's relationship with this Desdemona in Parker's production. (Potter 2002: 193)*** More substantial than in other film productions of Othello is the film narrative's hasty pace to convey its resentment and resistance to the Moor's act of marrying a white woman. A shot of Fishburne's Othello, for example, shows only hands, placing a ring on Desdemona's finger and kissing her clearly and rapidly, establishing their sealed secret marriage. A scene at night would only add to the intensity the hatred white culture holds against the

\footnotetext{
* This appreciative gaze of Desdemona marks Othello's new subject status, after he had been an object for and of white voyeurism.

** Parker's Othello sets such a good example of a film text that both keeps an eye on the dramatic, textual grandeur of the original script and keeps away from the narratological line of the source text to produce its own.

*** This excellent Parker's production played out this modern gender issue in the way that viewing the film would likely orient the spectator to read the Moor's story in the light of more similar narrative of the Simpsons' genre and through refashioning Iago as a wifeabuser too. All adds to the ability of Shakespeare's tragedy to ascend the echelons / aches of modernity and to reflect its problems.
} 
Moor. Perhaps the slow deliberateness of the Moor's words, articulated with clipped snappish English directness, all stand distinct from the Duke, Brabantio and Desdemona who speak with conspicuous clear European accents.*Unlike other film productions that try all camera strategies to show Othello's jealous fantasies, Parker's version gives no single indication that they are mere fantasies. (Potter 2002: 194)**

The film's relentless effort to preserve Shakespeare's grand drama did not evade the text's thrust for a modern setting different from Parker's intended Renaissance context. Unexpectedly, after the film's release, contemporary parallels presented themselves irresistibly. Played in a number of movie-theatres across the USA in late 1995 and early 1996, a Shakespearean story-line about a successful high profile black man living forcefully in a predominantly white world (USA, Venice), married to a white woman of royal siege- as is Othello-, made sexually envious, driven vehemently to violent extremes and ultimately accused of her tragic murder could only take some serious topical contemporary character.(see Buchanan 2002: 192) In Othello's and O.J. Simpson's stories, the protagonist was a black man being celebrated by white society for his heroic acts in a masculine, combative mode (Soldiery and Soccer) and who had both refused to allow themselves to be confined by restrictive definitions of his colour. In each case, both Othello and Simpson got married to a white woman (Desdemona and Nicole Brown) attracting paparazzi and firing a blaze of publicity and rightly or mistakenly both suspected their women of having sexual affairs with a white male adversary (Cassio and Roland Goldman). Both Othello and Simpson confined their expression of personal remorse to a blunt accusation of having loved his wife 'too well' or 'so much'. J.O. Simpson wrote a tear-eliciting suicide note addressed "to whom it may concern"- "I loved her. I always have and I always will. If we had a problem, it's because I loved her so much". Later, Simpson wrote, "Ilove her; make that clear to everyone."***Although Othello was representative of a traditional Venetian dogma and he lived a social dilemma after his disputable marriage to Desdemona, Simpson, being repositioned in a modern American context, would invoke similar suicidal tendencies of the same intensity. After the murder, each displayed similar self-dramatising

\footnotetext{
* Such a mere linguistic feature would most definitely add to Othello's rejected otherness. This is my own reading and interpretation of the story. This linguistic contrast adds up to the comic phase of Shakespeare's play.

** Parker has inserted flashbacks into the original narrative structure to illustrate Othello's disturbed mind.

*** The full note of Simpson's letter is cited in the New Times.com / 1994 / 06 / 18 / theSimpson- case- text, Published June 18th, 1994. Such a clear confession of his love to Nicole Brown echoes Othello's description of his platonic love to his Desdemona. 'One that loved not wisely, but too well'. (5. 2)
} 
affinities. The Moor delivered a self-vindicating obituary for himself just before his public suicide and Simpson remarkably held a gun to his head in the glare of the Television cameras on a Los Angeles freeway. (see Buchanan 2002: 193)

In her 'Race-ing Othello, Re-engendering White-out', Barbara Hodgdon (1997: 23) writes that "on Friday, 17 June, 1994, Shakespeare became a voice-over for a moment of American cultural history." More a commonplace American tragedy, the Simpsons' case redraws a new textual reference to Shakespeare's tragedy. Reporting that a suicidal O.J Simpson lay in his car holding a gun to his head, a CBS Television reporter even glossed his adverting flickering image of the vehicle, saying that he was reminded of Othello, where a black man suspects his wife of adultery to finally kill her and then himself. (Ibid.) Although some difference exists in the act of narration of the two stories, the Simpsons' story ending does not replicate Othello's ending. The American story, however, lends some evidence connecting these events of Simpsons' case to the universal critical, theatrical, and cultural legacy of Shakespeare.(Ibid.)

These non-finite parallels between O.J. Simpson's story and Othello's will have even become part of the critical orthodoxy of the play itself and more particularly about Parker's film production with its glorious African American in the title role. The film production therefore plays to the same traditional prejudices about the black African American and his remarkable sexuality that the O. J Simpson affair performed, articulating the complexity of American society. The film even plays out these prejudices introducing the 'aggressive black ram' besmirching the 'white ewe', and it flirts with the implication of this aggression in Othello's sexual relation with Desdemona from the very opening scenes of love-making in his fantasy.(see Buchanan 2002: 195) Writing into such a canonic tradition featuring black African Americans as sexual aggressors, the film has also been utterly outrageous in the way that it assigns to itself the task of including or even excluding black African Americans in modern America. Is Parker's faithful production an appropriate platform to test the adaptability of Shakespeare's Othello to modern times in the country?

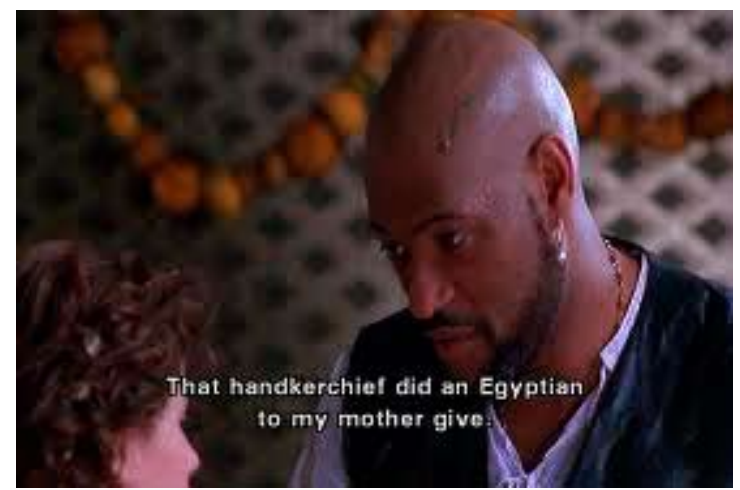




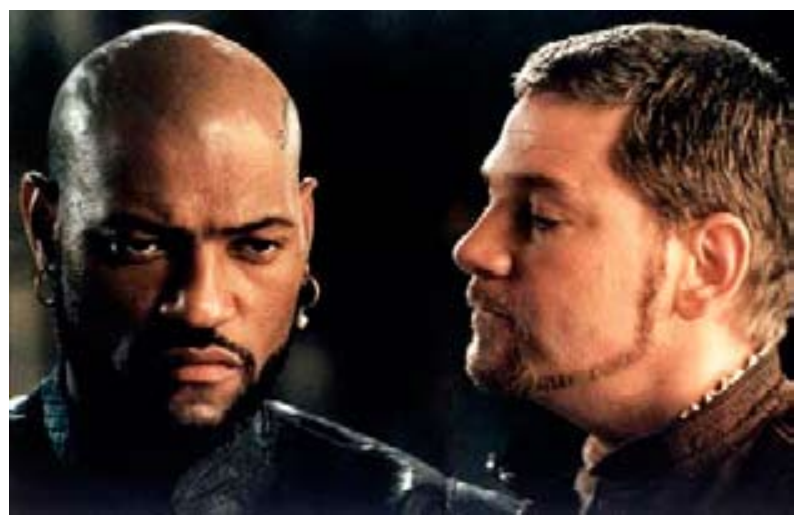

Othello and Iago

If in other film productions of Othello, each director tends to establish some prevailing mode of narration all to demonstrate an aspect of the Venetian respect of the Moor with the exception of Parker's approach through which Branagh's Iago becomes the hero of the piece.* While in his Avant-gardist adaptation Welles relies on visual effects to magnify and amplify this heavily art text and to contribute considerably to the portrayal of Othello, in Parker the realistic subtleties of the production float, adding to the artistic feature of the entire work. (Tatspaugh 2007: 150,153) Having been influenced mostly by Welles and Yutkevich, Parker has taken up a tradition of realism much closer to other 'Shakespeare fans' like Franco Zeffirelli, to name but a few. (Ibid.: 153)** Parker has been harshly castigated for his playing a higher percentage of Shakespeare's text than have Welles or Yutkevich. His staging of unscripted scenes has however helped Fishburne and Iren Yacob perform a compelling attraction between Othello and Desdemona unlike Welles's film that falls short in communicating the marriage as a 'love match'; especially that its deep formality also undermines the tragic intent of the entire Shakespeare's text. (Ibid.: 153, 151)

Rita Kempley wrote in the Washington Post, "Kenneth Branagh doesn't just steal the show; one suspects he might have sat in the director's chair as well."'(Kempley 1995) If, in most productions of Othello, the racist propaganda is championed most explicitly and most offensively by Iago, Parker's Iago makes the spectator inevitably conscious of the camera's essential role in building up the drama

\footnotetext{
* A major tone in Parker's film has been his Branagh's Iago as the narrator of the story. Refashioning Iago this way will even strike higher records by changing altogether Shakespeare's first narrative structure through which the Moor is the tragic hero in all respects while in Parker Iago occupies larger space.

** Yutkevich reads Othello as 'the tragedy of faith, the tragedy of trust and treachery'. (Ibid.: 152)
} 
by manually obscuring it as he discloses the different details of the plot.(see Buchanan 2002: 192) In this particular production of the tragedy, the camera- I mean here Iago- is the driving force that 'enmeshed' them all. It is the camera's characterization of the subjectivized gaze that builds up the entire drama in Parker's adaptation. So artful was the visual strategy of the camera lenses in lining up with Iago and ultimately with Desdemona's desirous gaze throughout the film whilst both tend to orient the camera towards Othello's body, a body that was intentionally and explicitly eroticized.(Ibid.: 184) Other instances of the work Branagh's Iago brought into the text were how he manages to put his blackened hand over the camera lenses as he announces his devilish nature to construct "a net, that shall enmesh them all"* Fishburne's performance as a black man playing the Moor reduces the huge gap between the player and the part played.**

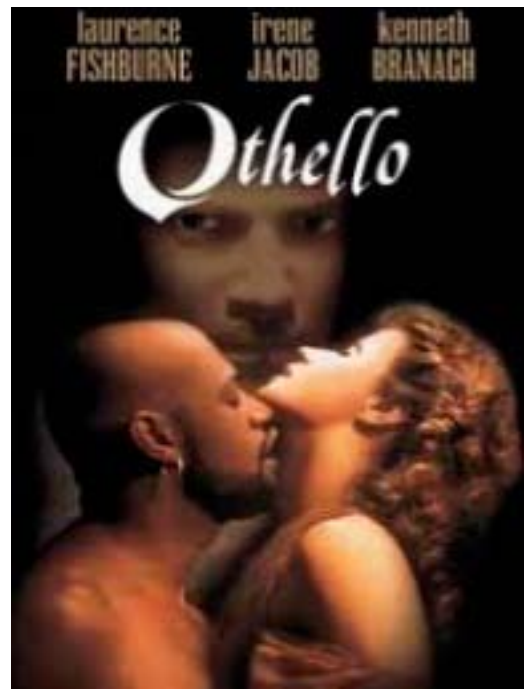

The film has been marketed as 'an erotic thriller' and this advertising poster played up the eroticism of the sexual union of Othello and Desdemona.

\footnotetext{
* Branagh's Iago speaking.

** There are other productions where Othello was played by a blackened up actor; such instances were Jannings, Welles, Olivier, and Hopkins, where the performance of drama was not as formidable as in Parker's cinematic work.
} 


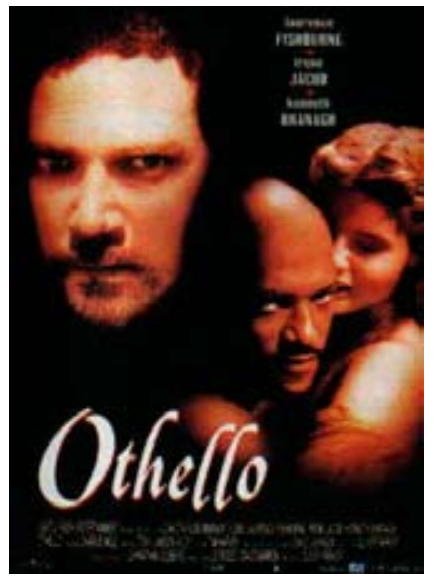

Other advertising posters emphasize the nature of the film as 'an erotic thriller'.

Prior to the artistic and cultural merits of Parker's work was that although film scholars argue that Branagh's Iago is the hero of the piece, Parker has however managed to deny his Iago this agency -that seems to float in some scenes-.of constructing the images we see. He has now been reduced, diminished and even objectified. Parker would even claim this new position to his Iago through an unyielding number of high angle shots where Branagh's is a vulnerable Iago. In conclusion, I would fully endorse Barbara Hodgdon's views through which she reads Oliver Parker's Othello as "an allegory of America's fear and desire from inter-racial eroticism" within a "white male viewer's potentially racist" (Hodgdon 2003: 91 qtd. in Aldama 2006: 198) if not racialist ruled by a potentially misogynistic secular economy. Although it preserves much of Shakespeare's poetry, the film is however a new mediatising form produced at an age "the white elite uses filmic representations of African Americans" as means to control and even contain race relations in the USA.(Ibid.)

'Constructing Black Masculinity in Oliver Parker's Othello (1995)' looks at the ways in which Laurence Fishburne's Othello had been styled as a man willing to resist the very circumstances he was living in. Featuring the first black actor in the title role in a corporate cinema project, Fishburne could not efface or minimize the already fixed social and physical difference. Parker, the film director, could only perceive him as a fascinating yet useful black outsider.

\section{References:}

Agassiz 1996: Agassiz L. White-Washing the Black-a-Moor: Othello, Negro Minstrelsy and Parodies of Blackness. - Journal of American Culture. Volume 19, Issue 3. 87-101. 
Aldama 2006: Aldama F. L. Race, Cognition, and Emotion. - College Literature. vol. 33 (1), Cognitive Shakespeare: Criticism and Theory in the Age of Neuroscience (Winter, 2006), 197-213.

Buchanan 2002: Buchanan J. Virgin and Ape, Venetian and Infidel: Labellings of Otherness. - In: Mark Thornton Burnett and Romana Wray (eds.). Oliver Parker's Othello' in Shakespeare, Film, Fin de Siècle. UK: Palgrave Macmillan. 179-202.

Davies 2011: Davies A. An Extravagant and Wheeling Stranger of Here and Everywhere. Characterizing Othello on Film: Exploring Seven Film Adaptations. - Shakespeare in Southern Africa. vol. 23, 11-19.

Hodgdon 1997: Hodgdon B. Race-ing Othello, Re-engendering White-out. - In: Boose L. E., B. Richard (eds.). Shakespeare The Movie: Popularizing the Plays on Film, TV and Video. Britain: Routledge, Taylor and Francis Group. 23-45.

Jones 1962: Jones J. On Aristotle and Greek Tragedy. USA: Chatto and Windus LTD.

Kempley 1995: Kempley R. Othello (R). - Washington Post. $29^{\text {th }}$ December, 1995. <http:// www.washingtonpost.com/wp-srv/style/longterm/movies/videos/othellorkempley_ c03fe2.htm>. [Accessed 15 Sept. 2017]

Peter 2009: Peter G. Platt's Shakespeare and the Culture Paradox. USA: Ashgate Publishing Limited.

Potter 2002: Potter L. Othello: Shakespeare in Performance. Manchester: Manchester University Press.

Rabkin 1967: Rabkin N. Shakespeare and the Common Understanding. New York: the Free Press.

Robesson 1995: Robesson P. Some Reflections on Othello and the Nature of Our Time. American Scholar, 14. 4, 391-392.

Rovisco, Kim 2014: Rovisco M., S. Kim. Cosmopolitanism, Religion and the Public Sphere. New York: Routledge.

Rutter 2000: Rutter C. Ch. Looking at Shakespeare's Women on Film. - In: Jackson R. (ed.). The Cambridge Companion to Shakespeare on Film. Cambridge, U.K: Cambridge University Press. 245-266.

Schur 2009: Schur R. Narrating African American Subjectivity through the Body: Critical Race Theory and Legal Discourse. - In: Henderson C. E. (ed.). America and the Black Body: Identity Politics in Print and Visual Culture. USA: Associated University Press. 29-54.

Tatspaugh 2007: Tatspaugh P. The Tragedies of Love on Film. - In: Jackson R. The Cambridge Companion to Shakespeare on Film. USA: Cambridge University Press. 141164.

The Simpson Case 1994: The Simpson Case; Text of the Letter From O. J. Simpson. - The New Times.com, Published June 18 ${ }^{\text {th }}, 1994 .<$ http://www.nytimes.com/1994/06/18/us/ the-simpson-case-text-of-the-letter-from-o-j-simpson.html $>$. [Accessed 15 Luly 2017]

Wallace 2002: Wallace M. O. Constructing the Black Masculine: Identity and Ideality in African American Men's Literature and Culture, 1975-1995. Durham and London: Duke University Press.

Willson 2002: Willson R. F. Jr. Strange New Worlds: Constructions of Venice and Cyprus in the Orson Welles and Oliver Parker's Films of Othello. - Shakespeare Bulletin. 20.3 (Summer 2002), 37-39. 